\title{
Protective effect of Salvia officinalis against cypermethrin- induced reprotoxicity in male Wistar rats
}

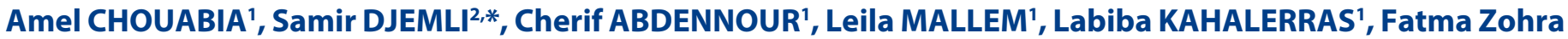 \\ ARKOUB' ${ }^{1}$, Narimene BOUABDALLAH ${ }^{1}$, Abdelkrim TAHRAOUI ${ }^{2}$
}

\section{Amel CHOUABIA 1 , Samir DJEMLI ${ }^{2, *}$, Cherif ABDENNOUR', Leila MALLEM', Labiba KAHALERRAS', Fatma Zohra ARKOUB ${ }^{1}$, Narimene BOUABDALLAH ${ }^{1}$, Abdelkrim TAHRAOUI}

${ }^{1}$ Faculty of Sciences, Animal Ecophysiology Laboratory, Department of Biology, Badji Mokhtar University, Annaba, ALGERIA.

${ }^{2}$ Faculty of Sciences, Applied

Neuroendocrinology Laboratory,

Department of Biology, Badji Mokhtar

University, Annaba, ALGERIA.

\section{Correspondence}

\section{Samir DJEMLI}

Faculty of Sciences, Applied

Neuroendocrinology Laboratory,

Department of Biology, Badji Mokhtar

University, Annaba, ALGERIA

E-mail: s_djemli@yahoo.fr

History

- Submission Date: 15-06-2021:

- Review completed: 21-07-2021;

- Accepted Date: 04-08-2021.

DOI : 10.5530/pj.2021.13.179

Article Available online

http://www.phcogj.com/v13/i6

\section{Copyright}

(C) 2021 Phcogi.Com. This is an openaccess article distributed under the terms of the Creative Commons Attribution 4.0 International license.

\begin{abstract}
Background: Medicinal plants are a reservoir of biologically active compounds with therapeutic properties that, over time, have been used for the treatment of various diseases. This study aims to evaluate the protective effect of the aqueous extract of the leaves of Salvia officinalis against cypermethrin-induced toxicity. Methods: 30 male rats weighing approximately $240 \mathrm{~g}$ were divided into equal six groups; the control group received tap water, the positive control received the aqueous extract of sage leaves (SLE) at a dose of $(0.5 \mathrm{~g} / \mathrm{kg} \mathrm{bw})$, the groups treated with cypermethrin (Cyp1) at $8.33 \mathrm{mg} / \mathrm{kg}$ bw and (Cyp2) at $25 \mathrm{mg} / \mathrm{kg} \mathrm{bw}$, and the groups treated by cypermethrin combined with aqueous extract of sage SLE+Cyp1 $(0.5 \mathrm{~g} / \mathrm{kg} \mathrm{bw}+8.33 \mathrm{mg} / \mathrm{kg} \mathrm{bw})$ and SLE+Cyp2 $(0.5 \mathrm{~g} / \mathrm{kg} \mathrm{bw}+25 \mathrm{mg} / \mathrm{kg}$ bw) for four days $/$ week. After 4 weeks of oral administration, epididymal seminal fluid was analyzed via the CASA system, in addition to the histological study testis and epididymis. Results: The obtained results showed a decrease in the absolute weight of the reproductive organs, with a significant decrease in sperm concentration, motility and speed in the cypermethrin-treated group compared to the control. Histological study of the testes and epididymis indicates an alteration in the stages of spermatogenesis in groups Cyp1 and Cyp2 compared to the control. However, the above-mentioned parameters were maintained almost normal in the groups that received the aqueous extract of sage with both doses of cypermethrin. Conclusion: it can be demonstrated that SLE has been shown to protect rats from cypermethrin-induced reprotoxicity Key words: Cypermethrin, Toxicity, Spermatozoa, Histology, Salvia officinalis, Rats.
\end{abstract}

\section{INTRODUCTION}

Pesticides are toxic chemicals that are deliberately introduced into the environment to kill off pests as well as rodents, fungi, insects, and weeds ${ }^{1}$. The use of pesticides is beneficial in general, but the excessive and misuse of these chemicals leads to impairment of human and animals' health ${ }^{2}$.

The widespread use of insecticides in agriculture to increase food production has become a major problem in developing countries, which is linked to various toxic activities ${ }^{3}$. Pyrethroids are among the most widely used insecticides ${ }^{4}$. Cypermethrin is a synthetic pyrethroid type (II) that is widely used in agriculture and other domestic applications ${ }^{3}$.

Recent studies have shown that expose to cypermethrin may cause serious health impairments for humans and animals, including, nervous, immune, endocrine, hematology, cardiovascular, respiration, and reproductive system ${ }^{5}$. The reports of reproductive toxicity of cypermethrin has affected spermatogenesis leading to poor semen quality and reduced male fertility ${ }^{6}$. Other studies indicated that treatment of rabbit with cypermethrin caused a decrease in sperm concentration, sperm motility, and an increase in the number of abnormal and dead spermatozoa ${ }^{7}$. Furthermore, cypermethrin exposure has disrupted the pituitary receptor and provoked hormonal imbalance of FSH, LH and testosterone ${ }^{8}$.

Currently, there is an increased request for the use of herbal therapy, instead of using synthetic drugs, which could have harmful effects and therefore may perhaps be more dangerous than the disease itself $^{9}$.

Salvia officinalis is an annual herb of the Lamiaceae (Labiatae) family, which grows in countries bordering the Mediterranean Sea and today it has been naturalized throughout the world ${ }^{10}$. For thousands of years, this plant has been used in many Countries as a spice and food preservative as well as a health remedy in traditional folk medicine for the treatment of numerous disorders ${ }^{11,12}$.Salvia officinalis is considered the most powerful source of antioxidants among plant herbs ${ }^{13}$, which is due to the complex mixture of monoterpenes, diterpene, sesquiterpenes, flavonoids and phenolic acids. It contains also other phytoconstituents such as cineol, borneol, rosmarinic acid, chlorogenic acid, salvianolic acid or vitamin $\mathrm{C}$ and $\mathrm{E}^{14,15}$. A review of the literature revealed that hydroethanolic leaf extract of $S$. officinalis showed the highest total flavonoid and phenolic content and antioxidant capacity ${ }^{16}$. It has been confirmed that those products also have multiple pharmacological effects including antibacterial ${ }^{17}$, anti-diarrhea ${ }^{18}$, anti-inflammatory ${ }^{19}$, anti-hyperglycemic ${ }^{20}$, anti-proliferative ${ }^{21}$, immunomodulatory ${ }^{22}$, ant-imutagenic ${ }^{23}$, and anti-cancer effect ${ }^{24}$. Indeed, the existence of these compounds presumably makes $S$. officinalis a potent source against different types of detrimental effects caused by xenobiotics..$^{14,15}$

Hence, this study designed to evaluate the protective effect of the aqueous extract of Salvia officinalis (sage) against the reproductive toxicity associated with cypermethrin in male Wistar rats. 


\section{MATERIALS AND METHODS}

\section{Insecticide}

Technical grade of cypermethrin (Meghmani organics limited, Panoli, Bharuch, India) was obtained from agro store in Annaba, Algeria.

\section{Plant}

The aerial part of Salvia Officinalis L. was harvested in June, 2019 from the region of Annaba, Algeria. The fresh leaves were washed and then grounded in distilled water with a homemade mixer into small pieces; finally, the obtained aqueous extract was filtered using cotton gauze.

\section{Animals}

This study was carried out on 30 Wistar male rats procured from Pasteur institute of Algeria. Animals were maintained under standard conditions in polypropylene cages, offered commercial food pellets (Oued Fraga, Guelma, Algeria) and water ad libitum, and then theyleft to acclimatize for one week before the experiments.

\section{Experimental design}

Rats with a body weight of $240 \pm \mathrm{g}$ were divided into six equal groups as follows:

\section{- Control group (C): received tap water}

- Positive control group (SLE): received $500 \mathrm{mg} . \mathrm{kg}$ bw of sage leaves aqueous extract

- Group (Cyp1): received 1/30 LD50 of cypermethrin (8.33 mg/kg bw)

Group (Cyp2): received 1/10 LD50 of Cypermethrin ( $25 \mathrm{mg} / \mathrm{kg} \mathrm{bw})$

-Group (SLE+Cyp1): received a combination of SLE with Cyp1 $(500 \mathrm{mg}+8.33 \mathrm{mg} / \mathrm{kg} \mathrm{bw})$

- Group (SLE+Cyp2): received a combination of SLE with Cyp2 (500g $+25 \mathrm{mg} / \mathrm{kg} \mathrm{bw}$ ).

The sage leaves aqueous extract and Cypermethrin were administrated orally for five days a week during one month.

\section{Organ's weight}

At the end of the treatment period, the rats of the different groups are sacrificed by decapitation. Testis and epididymis were removed, trimmed of fat and weighed using a precision balance (K E R N PRS 320-3).

\section{Semen analysis}

Semen analysis was realized using the Computer-Assisted Sperm Analysis Method (CASA) using Sperm Class Analysis (SCA ${ }^{\circ}$, Microptic, Barcelona, Spain). The epididymal semen was obtained immediately after sacrifice, and then a drop of semen was diluted with a physiological solution of $\mathrm{NaCl} 0.09 \%$, and then $5 \mu \mathrm{L}$ of the mixturewas put in a chamber slide (GoldCyto model). The slide was then placed on a Nikon Eclipse (E200-LED) microscope at the phase objective $(\times 4)$. The concentration, motility and speed of sperm were calculated.

\section{Histological study}

The testes and epididymis samples were examined for histopathological changes. They were placed in $10 \%$ formol and dehydrated in $70-$ $100 \%$ ethanol series, and then they placed in paraffin baths at $58^{\circ} \mathrm{C}$. Sections of 4-6 $\mathrm{mm}$ were prepared from paraffin blocks using a rotary microtome. These sections were then stained with Hematoxylin-Eosin (H-E) according to the criteria of the method of ${ }^{25}$, and then the slides were photographed using a Leica photomicroscope.

\section{Data analysis}

The obtained results were expressed as a Mean \pm SEM. Statistical analysis of the data was performed by one-way analysis of variance (ANOVA), followed by Tukey's test using prism 5 software. The significant test was considered at $\mathrm{p}<0.05$.

\section{RESULTS}

\section{Organs absolute weight}

The obtained results showed a highly significant decrease in testes weight in the group treated with the two doses of cypermethrin compared to the control group. On the other hand, the oral administration of SLE+Cyp1and SLE+Cyp2 to rats increased the weight of the testes in a highly significant way (tab.1) compared to group treated with cypermethrin only. Epididymal weight showed a significant decrease in animals of group Cyp2 compared to the control group (C). However, we recorded a highly significant increase in epididymis weight in group (SLE2) rats compared to group Cyp2.

\section{Sperm concentration and motility}

Table 2 demonstrates the results obtained after exposure to sage extract and cypermethrin on sperm parameters of adult male rats. Epididymal sperm concentration was reduced significantly in males that ingested 8.33 and $25 \mathrm{mg} / \mathrm{kg}$ bw of cypermethrin. On the other hand, the treatment with the combination of cypermethrin and leaves aqueous extract of Silvia (SLE1 and SLE2) increased in a highly significant way compared to group (Cyp1) and (Cyp2), respectively. For sperm motility, results represented by (Tab 2 ) showed a very highly significant decrease in the group of Cyp1 and Cyp2 groups compared to the control. Nevertheless, rats treated with the combination of sage aqueous extract and cypermethrin revealed a significant increase in sperm motility compared to rats treated with cypermethrin alone.

\section{Sperm velocity}

Results of rat sperm velocity of all groups are summarized in Figure 1.

Rapid sperm velocity was significantly decreased in the rats of the (Cyp1) and (Cyp2) groups compared to the control. In contrast of that, there was a very highly significant increase in the groups treated with the combination of sage and cypermethrin (SLE+Cyp1 and SLE+Cyp2) compared with the groups treated only with cypermethrin.

Table 1: Variation in absolute testicular and epididymal weight (g) in the six groups of rats exposed to SLE and Cyp(Mean $\pm S E M, n=5$ ).

\begin{tabular}{lll}
\hline Groups & Testis weight $(\mathrm{g})$ & Epididymis weight $(\mathrm{g})$ \\
\hline C & $1.64 \pm 0.03$ & $0.49 \pm 0.01$ \\
SLE & $1.56 \pm 0.01$ & $0.49 \pm 0.01$ \\
Cyp1 & $1.02 \pm 0.20^{\mathrm{a}}$ & $0.45 \pm 0.03$ \\
Cyp2 & $0.60 \pm 0.22^{\mathrm{ab}}$ & $0.37 \pm 0.002^{\mathrm{ab}}$ \\
SLE+Cyp1 & $1.62 \pm 0.02^{\mathrm{cd}}$ & $0.51 \pm 0.01^{\mathrm{d}}$ \\
SLE+Cyp2 & $1.62 \pm 0.02^{\mathrm{cd}}$ & $0.50 \pm 0.03^{\mathrm{d}}$
\end{tabular}

Table 2: Variation of sperm concentration $\left(10^{6} / \mathrm{mL}\right)$ and motility $(\%)$ in the six groups of ratsexposed to SLE and Cyp (Mean $\pm S E M, n=5$ ).

\begin{tabular}{lll} 
Groups & $\begin{array}{l}\text { Sperm concentration } \\
\left(10^{6} / \mathrm{ml}\right)\end{array}$ & $\begin{array}{l}\text { Sperm motility } \\
(\%)\end{array}$ \\
\hline C & $62.33 \pm 0.50$ & $54.09 \pm 3.40$ \\
SLE & $63.48 \pm 7.90$ & $59.44 \pm 7.16$ \\
Cyp1 & $19.34^{\mathrm{ab}} \pm 4.42$ & $17.89^{\mathrm{ab}} \pm 6.71$ \\
Cyp2 & $21.93^{\mathrm{ab}} \pm 0.71$ & $23.26^{\mathrm{ab}} \pm 4.35$ \\
SLE+Cyp1 & $51.83^{\mathrm{cd}} \pm 4.44$ & $51.48^{\mathrm{c}} \pm 4.43$ \\
SLE+Cyp2 & $56.87^{\mathrm{cd}} \pm 4.25$ & $55.24^{\mathrm{cd}} \pm 9.11$
\end{tabular}




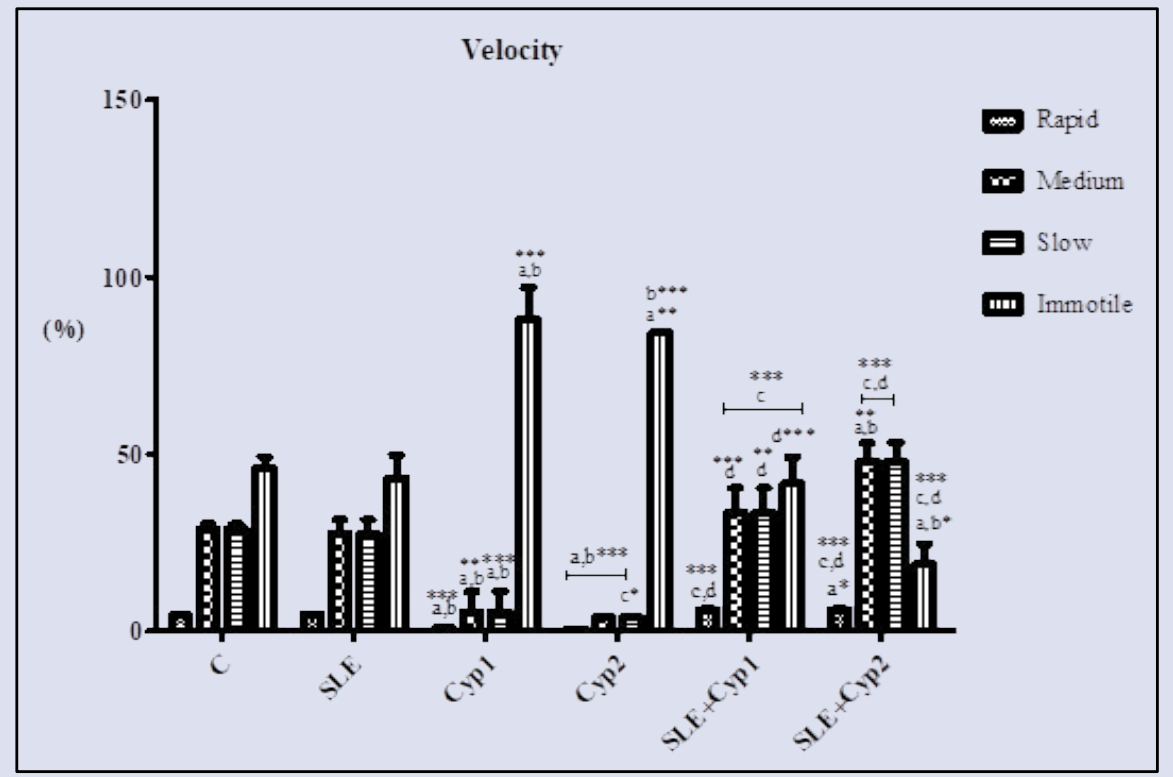

Figure 1: Variation in sperm velocity (\%) in the six groups of rats (Mean $\pm S E M, n=5$ ).

Treatment of rats with Cyp1 and Cyp2 induced a significant decrease in mean sperm velocity compared to the control. In the other hand, sage aqueous extract combined group significantly increased the mean sperm velocity in SLE+Cyp1 group compared to Cyp1 and very highly significantly in the and SLE+Cyp2 group compared to the Cyp2 group.

Slow sperm velocity results illustrated a highly significant decrease in the group treated with the low dose of cypermethrin (Cyp1) compared to the control. However, a highly significant increase was recorded in the SLE+Cyp1 group compared to the Cyp1 group and a significant increase in the SLE+Cyp2 group compared to the Cyp2 group.

The percentage of immobile sperm significantly increased in groups exposed to cypermethrincompared to the control. Also, a highly significant decrease in immobile sperm is recorded in the rats of the group treated with the combined group SLE+Cyp1 compared to Cyp1 group, and a very highly significant increase in the group treated with SLE+Cyp2 compared to the Cyp2 group.

\section{The testicular histology}

The photomicrography of the transverse section in the seminiferous tubules of the testes of rats in the control and treated group is illustrated in figure 3 . The control groups (c) showing seminal tubes with normallooking spermatogenesis, mature spermatozoa fill almost all the lumen of the seminal tubes that respect its diameter. Likewise, the positive control group (SLE) showed a normal tissue in good condition (defining all stages of spermatogenesis), similar to the control group. While the treated group (Cyp1) showed the presence of some vacuolization, circular empty zones, luminal spermatozoa reduction, we can say that cypermethrin has affected the course of spermatogenesis. Furthermore, CYP2 treated group showed somniferous tubules with low intensity compared to the control group. There was also an alteration in the first stage of spermatogenesis which may be due to cell necrosis or apoptosis caused by the toxic product, resulting in the absence of spermatogenic cells. However, (SLE+Cyp1) group showed a return to the normal overall structure of the testis compared to (CYP1) group. In regards to (SLE+Cyp2) group, we noticed a decrease in spermatozoa of seminiferous tubules compared to the CYP2 group. But it can be noted that the administration of the aqueous extract may have improved the overall structure of the testicle.

\section{The epidydimal histology}

The control (c) and positive control (SLE) groups showed normal tissue with an epididymal tubes lumen full of spermatozoa. While in treated groups (Cyp1) (Cyp2) we noticed an alteration and a decrease of spermatozoa in the lumen of the epididymal tubes compared to the control groups (c) and (SLE). Nonetheless, in (SLE+Cyp1) group we observed an increase in sperm density in the epididymal ducts compared to CYP1 group. We have also remarked a decrease in sperm density in (SLE+Cyp2) group, as compared to the CYP2 treated group.

\section{DISCUSSION}

Exposure to toxic substances from the environment may alter spermatogenesis, testicular morphology, and reduced reproductive organs weight ${ }^{26,27}$. Our experimental results indicate a highly significant decrease in testis absolute weight accompanied with a significant reduction in epididymis absolute weight in rats treated with cypermethrin. These results correlate well with those of ${ }^{28,29}$.There were several studies indicating that xenobiotics directly influence Sertoli cells function, hence spermatogenesis impairment and epithelial disorganization which may cause tubular atrophy ${ }^{30}$. Thus, the decrease in testis weight may be caused by regressive and necrotic changes with germ cells number reduction induced by cypermethrin in the seminiferous tubules ${ }^{29,31}$.The changes in epididymis weight could due to thealteration of tubules epithelial cells and reduction of sperm count in the epididymis lumen ${ }^{32}$ In addition, the decrease in organs weight might also be to the oxidative stress induced by cypermethrin, leading to spermatogenic cells necrosis associated with sperm abnormalities ${ }^{33}$.

The decrease in testicular and epididymal weights has also corresponded to the histopathological and cytopathological changes of the male reproductive system ${ }^{34}$.The present study indicated that cypermethrin caused regressive histological changes in the seminiferous tubules, resulting in the suppression of spermatogenesis, expansion of interstitial spaces, vacuolization, and circular empty zones. Our results are in agreement with the results of ${ }^{35}$ who found significant decrease in the cell layers of testicular somniferous tubules, which contained a large number of immature spermatids, congested blood vessels, vacuolization, and marked hemorrhage further significant thickening of the connective tissues surrounding the tubules in testes of 

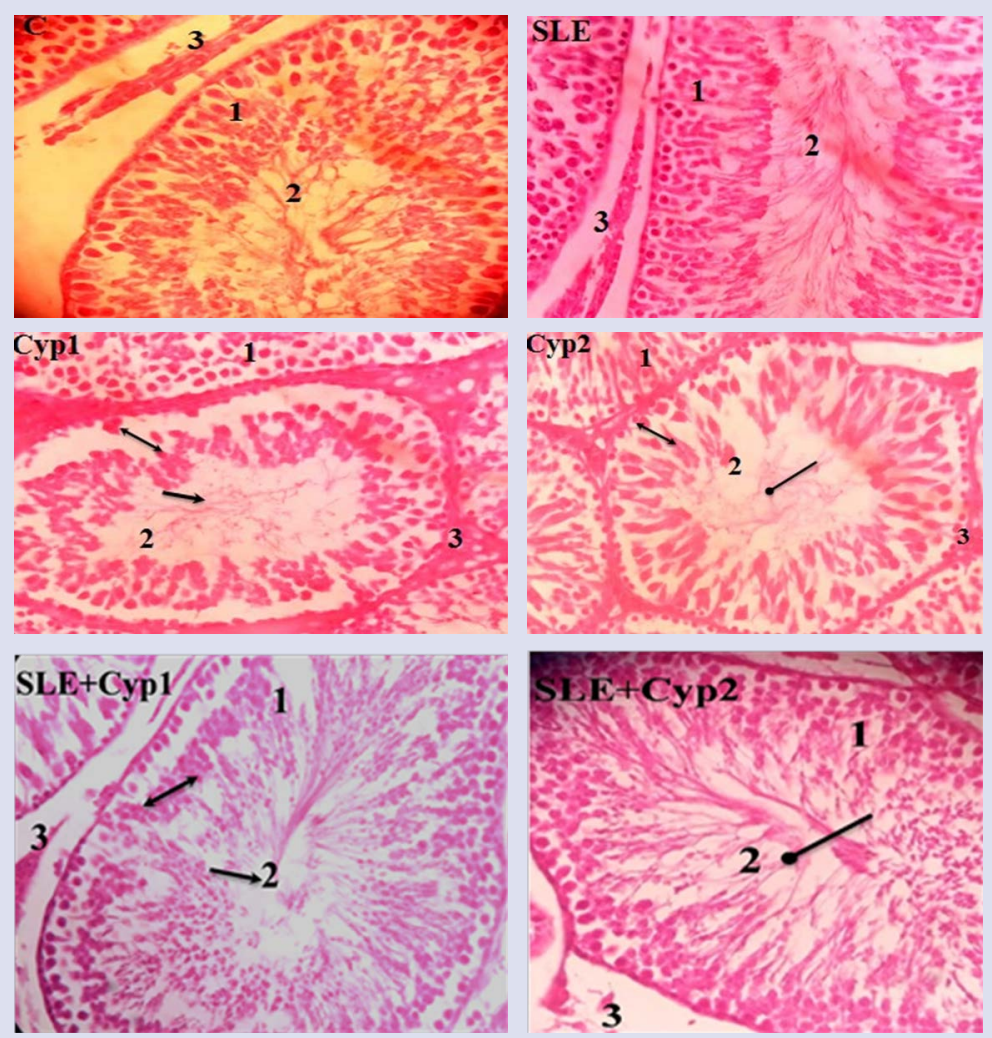

Figure 2: Photomicrography of transverse section in the somniferous tubules on the testes of rats in the control and treated group (H.E.400X). 1-Seminal tube, 2-Spermatozoa, 3- Leydig cell, ( $\rightarrow$ ) spz decrease, $(\boldsymbol{x})$ alteration ( $a$ ) Absence of $\mathrm{spz}$.
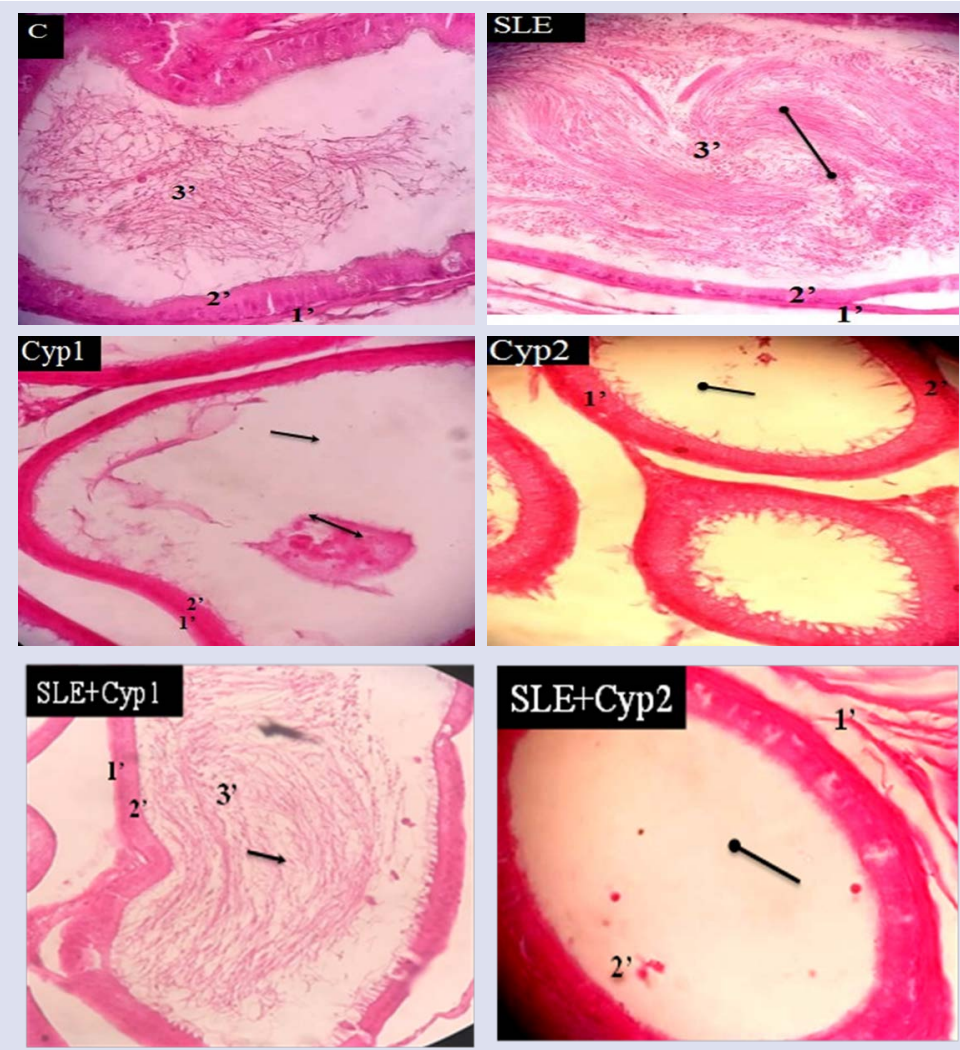

Figure 3: Photomicrography of transverse section in the epididymis tubules on the testes of rats in the control and treated group (H.E.400X).

1'- The limiting membrane, 2'- The epithelium, 3'-Spermatozoa. ( $\Delta$ ) spz decrease, ( $*$ ) alration, ( $a$ )Absence of spz, (a) increase of spermatozoa. 
ratstreated with cypermethrin.In support, a wide array of abnormalities represented in a degenerative changing in spermatogonia cells, necrosis, and separating of cells from basal region of somniferous tubuleswere seen in histological sections of the testes after cypermethrin exposure ${ }^{36}$.Epididymis morphology was also altered by cypermethrin and this was demonstrated by the alteration and the decrease of sperm count in the lumen of the epididymal tubules with a reduction of their diameters. These changes may be due to a disturbance in testosterone biosynthesis, which may provoke germinal epithelium seminiferous tubular degeneration, which is in line with spermatogenesis suppression and decrease of spermatozoa in testis and epididymis ${ }^{37,38}$.

Exposure to cypermethrin caused a significant reduction in sperm concentration in a dose dependent manner. The results are in agreement with ${ }^{35}$ whoreported that ingestion of 34,286 ppm cypermethrin for 12 weeks per male rats significantly reduced sperm count. Thus, cypermethrin may produce testicular steroidogenic alterations by affecting indirectly hypothalamus-pituitary axis or by acting directly on Leydig and Sertoli cells, leading to a decrease in testosterone biosynthesis; which is the key hormone of spermatogenesis regulation 39,40,41.Diminishing in sperm concentration may also be due to necrosis and loss of germ cells. ${ }^{39}$ demonstrated a degeneration and depletion of spermatocytes and spermatids in adult pheasants exposed to cypermethrin. The capacity of sperm production depends on the number of Sertoli cells ${ }^{40}$ which serve as support to germ cells' development ${ }^{41}$.

Regarding the drop in sperm mobility and velocity in the groups treated with the different doses of cypermethrin of the actual study, a reduction of net weight of testes was reported after oral administration of Cyp for 14 days ${ }^{8}$. Moreover, Cypermethrin can inhibit mitochondrial ATP production, which influences fructose synthesis, or spermatozoa microtubule structure ${ }^{42,43}$. Consequently, perturbations in mitochondrial activity can reduce the spermmovement by affecting sperm motility and velocity.Moreover, the detrimental effects of cypermethrin on reproductive performance can be associated to excessive free radical formation, which may causes sperm DNA damage and inhibit the activities of antioxidant enzymes leading to spermatogenic cells degeneration that is associated with sperm abnormalities. Likewise, oxidative stress is likely to produce membrane integrity damage therefore, decreased sperm motility and viability ${ }^{8,44}$. Recently, ${ }^{44}$ reported that non-occupational environmental pyrethroids exposure could have a negative impact on sperm DNA integrity and semen quality in Chinese males. Thus, the excessive ROS generation can induce oxidation of polyunsaturated fatty acids in membranes of sperm lipids, which alters the structure of lipid matrix that is associated with rapid loss of intracellular ATP leading to axonemal damage, increased mid-piece morphological defects, and inhibited spermatozoaactivity ${ }^{45}$.

On the other side, sage aqueous extract improved reproductive organs weight and sperm parameters when administrated simultaneously with cypermethrin. ${ }^{46}$ indicated that hydroalcoholic leaf extract of Salvia officinalis has excitatory effects on male reproductive system leading to increase in serum testosterone level and spermatogenesis. Such effect was perhaps linked toS. officinalis extract by improving the antioxidant defense system and suppressing the oxidative stress ${ }^{47}$. In addition, ${ }^{48}$ has demonstrated that aqueous extract of $S$. officinalis had a positive effect on some fertility parameters and pituitary-testicular hormone axis. The aqueous extract of sage had high content of flavonoids ${ }^{11}$, and was rich in cineol, borneol, pinene, saponin, glycoside, resin, vitamin $\mathrm{C}$ and $\mathrm{E}$, rosmarinic acid, chlorogenic acid, caffeic acid, methyl rosmarenate, cinnamic acid, quinic acid, ferulic acid, apigenin, luteolin, quercetin steroids and tannins ${ }^{49,50,51}$, endowed with a strong antioxidant power ${ }^{52,53}$. It has been reported that flavonoids have a series of biological effects such as lipid peroxidation reduction because of their antioxidant properties and their ability of removing free radicals and chelating divalent cations ${ }^{54,55}$. On the other hand, quercetin as an important dietary flavonoidhas has a prominent pharmacological effects, such as free radical scavenging ${ }^{56}$ theTNF- $\alpha$ inhibition ${ }^{57}$ which is an extensive factor that stimulates inflammatory pathway resulting of oxidative damage.It is also proved that quercetin has enhanced rats' sperm viability, motility, and serum total testosterone ${ }^{58}$. Furthermore, Vitamins $\mathrm{C}$ and $\mathrm{E}$ have a beneficial effect on male infertility treatment and sperm function ${ }^{59,60}$.

\section{CONCLUSIONS}

Based on these findings, we conclude that cypermethrin toxicity affectedreproductive function of adult male wistar rats,which is manifested in reduced organs weight, decreased sperm concentration, motility and velocity. Salvia officinalis has a beneficial effect on preventing cypermethrin-induced testicular damages by enhancing sperm quality, and this perhaps is linked to its phenolic and flavonoid compounds, which has free strong radicals' scavenging activity.

\section{CONFLICTS OF INTEREST}

The authors declare that there is no conflict of interest with this work.

\section{FUNDING}

This research did not receive any financial support.

\section{AUTHORS' CONTRIBUTIONS}

This work was carried out in collaboration among all authors.

\section{REFERENCES}

1. Matthews GA Pesticides: Health, Safety and the Environment. Blackwell Publishing, Oxford, UK 2006.

2. Eddleston $M$, Karalliedde L, Buckley $N$ Pesticide poisoning in the developing world-a minimum pesticides list. Lancet 2002; 360, 1163-67.

3. Sankar P, Telang AG, Manimaran A Effect of piperine on cypermethrin-induced oxidative damage in rats. J. Veterinar. Sci. Technol $2011 ; 2: 105$.

4. Sharma P, Huq A, and Singh R Cypermethrin induced reproductive toxicity in male Wistar rats: Protective role of Tribulus terrestris. Journal of Environmental Biology, 2013;34, 857-862.

5. Patil JA, Patil AJ, Sontakke AV, Govindwar SP Effect of Vitamin E Supplementation on Biochemical Parameters in Pesticides Sprayers of Grape Gardens of Western Maharashtra (India). Indian Journal of Clinical Biochemistry 2012; 27(2), 134-140. http://dx.doi. org/10.1007/s12291-012-0207-x

6. Falck F, Ricci A, Wolff MS, Godbold J, Deckers P Pesticides and polychlorinated biphenyl residues in human breast lipids and their relation to breast cancer. Archives of Environmental Health,1992; 47(2), 143-146. PMID: 1567239

7. Al-Hamdani N, Yajurvedi H Cypermethrin reversibly alters sperm count without altering fertility in mice. Ecotoxicol and Environ Saf 2010; 73:1092-1097.

8. Sharma $P$, UI Huq $A$, Singh $R$ Cypermethrin-induced reproductive toxicity in the rat is prevented by resveratrol. Journal of Human Reproductive Sciences 2014; 7(2): 99-106.

9. Mady NI, Allam AF, Salem Al Evaluation of the addition of Nigella sativa oil-triclabendazole therapy in the treatment of human fascioliasis. J. Egypt. Pharmacol. Exp. Ther 2001; 20, 807-827.

10. Gali-Muhtasib H, Hilan C, Khater C Traditional uses of Salvia libanotica (East Mediterranean sage) and the effects of its essential oils. J. Ethnopharma-col 2000; 71: 513. 
11. Lima CF, Carvalho F, Fernandes E, Bastos ML, Santos-Gomes PC, Fernandes-Ferreira M, Pereira-Wilson C Evaluation of toxic/ protective effects of the essential oil of Salvia officinalis on freshly isolated rat hepatocytes. Toxicology in Vitro 2004;18(4), 457-465. doi:10.1016/j.tiv.2004.01.001.

12. Abdallah IZA, Khattav H, Sawiress F, El-Banna RAS Effect of Salvia Officinalis L. (Sage) Herbs on Osteoporotic Changes in Aged NonCycling Female Rats. Med. J. Cairo Univ. 2010 ; 78(1): 1-9.

13. Madsen HL, Bertelsen G, Skibsted LH Antioxidative activity of spices and spice extracts. In: Risch SJ, Ho CT (Eds) Spices, Flavour Chemistry and Antioxidant Properties. American Chemical Society, Washington DC1997; pp. 176-187.

14. Kosar M, Dorman $\mathrm{Hj}$, Baser Kh, Hilltunen R Salvia officinalis $\mathrm{L}$.: composition and antioxidant-related activities of a crude extract and selected sub-fractions. Natural Product Communications 2010; 5: $1453-1456$.

15. Rahte S, Evans R, Eugster Pj, Marcourt L, WolfenderJI, Kortenkamp A, Tasdemir D: Salvia officinalis for hot flushes. Towards determination of mechanism of activity and active principles. Planta Medica 2013; 79, 753- 760.

16. Karimzadeh $\mathrm{S}$, Farahpour MR Toppical application of Salvia officinalis hydroethanolic leaf extract improves wound healing process, Inidan J of Experimental Biology 2017: 55 : 98-106.

17. Kontogianni VG, Tomic G, Nikolic I, Nerantzaki AA, Sayyad N, StosicGrujicic S, Stojanovic I, GerothanassisIP,Tzakos AG Phytochemical profile of Rosmarinus officinalis and Salvia officinalisextracts and correlation to their antioxidant and anti-proliferative activity. Food Chem 2013; 136:120.

18. Elkhoudri N, Baali A, Amor H Maternal morbidity and the use of medicinal herbs in the city of Marrakech, Morrocco. Inidan J TraditKnowl 2016; $15: 79$.

19. Korkmaz M, Karakuş S, Özçelik H, Selvi S An ethnobotanical study on medicinal plants in Erzincan, Turkey. Inidan J TraditKnowl 2016; $15: 192$.

20. Eidi M, Eidi A, Zamanizadeh $\mathrm{H}$ Effect of Salvia officinalis L. leaves on serum glucose and insulin in healthy and streptozotocin-induced diabetic rats. J. Ethnopharmacol 2005; 100: 310-313.

21. Kozics K, Klusová $V$, Srančíková A, Mučaji $P$, Slameňová $D$, Hunáková L', Horváthová E, Effects of Salvia officinalis and Thymus vulgaris on oxidant-induced DNA damage and antioxidant status in HepG2 cells. Foodchem 2013; 141: 2198.

22. Mukherjee PK, Nema NK, Bhadra S, Mukherjee D, Braga FC, Matsabisa $M$, Immunomodulatory leads from medicinal plant. Inidan J TraditKnowl 2014; 13: 235.

23. Bouaziz-Ketata H, Zouari N, SalahHB, Rafrafi M, Zeghal N Flavonoid profile and antioxidant activities of methanolic extract of Hyparrheniahirta (L.) Stapf. Indian J Exp Biol 2015; 53: 208.

24. Xavier CP, Lima CF, Fernandes-Ferreira M, Pereira- Wilson C Salvia fruticosa, Salvia officinalis, and rosmarinic acid induce apoptosis and inhibit proliferation of human colorectal cell lines: the role in MAPK/ERK pathway. Nutr.Cancer 2009;61: 564-571.

25. Martoja R and Martoja M Initiation aux techniques de I'histologie animale. Paris : Edition Masson 1967 ; 345p.

26. Adler RA. Clinical review 33: clinically important effects of alcohol on endocrine function. J Clin EndocrinolMetab 1992; 74(5):957-960.

27. Ren JC Banan A, Keshavarzian A Exposure to ethanol induces oxidative damage in the pituitary gland. Alcohol 2005; 35(2): 91-101.

28. Prahalathan $C$, Selvakumar E, Varalakshmi P Lipoic acid ameliorates adriamycininduced testicular mitochondriopathy. ReprodToxicol 2006; 20: 111-116.

29. Wang $X Z$, Liu SS, Sun $Y$, Wu JY, Zhou $Y L$, Zhang JH Betacypermethrinimpairs reproductive function in male mice by inducing oxidative stress. Theriogenology 2009;72:599-611.
30. Bedwal RS, Edwards MS, Katoch M, Bahuguna A, Dewan R. Histological and biochemical changes in testis of zinc deficient BALB/c strain of mice. Indian journal of experimental biology 1994; 32(4):243-7.

31. Choudhary N, Goyal R, Joshi SC. Effect of malathion on reproductive system 2008.

32. Zhou D, Zhang J, Wang H, Xue Y. Effect of formaldehyde exposure on structure and function of epididymis in adult rats: a histological and biochemical study. Toxicological\&amp; Environmental Chemistry 2010: 93(1), 134-144.

33. Sharma $P$, Singh $R$ Protective role of curcumin on lindane induced reproductive toxicity in male Wistar rats. Bull Environ ContamToxicol 2010;84:378-84.

34. Sarabia L, Maurer I, Bustos-Obregon E Melatonin prevent damage elicited by the organophosphorous pesticide diazinon on mouse sperm DNA. Ecotoxicol Environ Saf 2009; 72: 663-866.

35. Elbetieha A, Da'as SI, Khamas W, Darmani H Evaluation of the Toxic Potentials of Cypermethrin Pesticide on Some Reproductive and Fertility Parameters in the Male Rats. Archives of Environmental Contamination and Toxicology 2001; 41(4): 522-528.

36. Alaa-Eldin EA, El-Shafei D A, Abouhashem NS. Individual and combined effect of chlorpyrifos and cypermethrin on reproductive system of adult male albino rats. Environmental Science and Pollution Research 2016; 24(2), 1532-1543. doi:10.1007/s11356016-7912-6.

37. Li Yan Fang, PAN Chen, HU Jin Xia, LI Jing, and XU Li Chun Effects of Cypermethrin on Male Reproductive System in Adult Rats. Biomed Environ Sciences 2013; 26(3): 201-208.

38. Monet-Kuntz C, Hochereau-de Reviers MT, Terqui M Variations in testicular androgen receptors and histology of the lamb testis from birth to puberty. J ReprodFertil 1984;70:203-10.

39. Cigankova V, Kacmar P, Neuschl J, Tomajkova E, Poracova J, Konrad V. Light and electron microscopical observations on the pheasant testis after pyrethroid application. Folia Veterinaria. 1993; 37:95-8.

40. Orth JM, Gunsalus GL, Lamperti AA. Evidence from Sertoli celldepleted rats indicates that spermatid number in adults depends on numbers of Sertoli cells produced during perinatal development. Endocrinology 1988;122: 787-94.

41. Russell LD, Peterson RN Determination of the elongate spermatid-Sertoli cell ratio in various mammals. J ReprodFertil 1984; 70:635-41.

42. Uzunhisarcikli M, Kalender Y, Dirican K, Kalender S, Ogutcu A, Buyukkomurcu $F$ Acute, subacute and subchronic administration of methyl parathion-induced testicular damage in male rats and protective role of vitamins C and E. PesticBiochemPhysiol 2007; 87:115-122.

43. Heikal TM, Mossa AT, Ibrahim AW, Abdel-Hamid HF Oxidative damage and reproductive toxicity associated with cyromazine and chlorpyrifos in male rats: the protective effects of green tea extract. Res J Environ Toxicol 2014; 8:53-67.

44. Ji G, Xia Y, Gu A, Shi X, Long Y, Song L, Wang S, Wang X Effects of non-occupational environmental exposure to pyrethroids on semen quality and sperm DNA integrity in Chinese men. Reproductive Toxicology $2011 ; 31(2): 171-117$.

45. Henkel R The impact of oxidants on sperm functions. Andrologia 2005; 37: $205 \mathrm{e} 6$.

46. Ahmadi R, Balali S, Tavakoli P, Mafi M, Haji GR. The effect of hydroalcoholic leaf extract of Salvia officinalis on serum levels of $\mathrm{FSH}, \mathrm{LH}$, testosterone and testicular tissue in rats. journal of kashan university of medical sciences 2013; 17(3): 225-231. 
47. Ahmed MO, Ashour MB, Asran AEA, Ali MA. Assessment of the Preventive Effects of Salvia officinalis and Ruta graveolens Ethanolic Extracts on Chlorpyrifosand Methomyl-induced Testicular and Cardiac Toxicities in Albino Rats. American Journal of Medicine and Medical Sciences 2017; 7(7): 287-301.

48. Alchalabi S, Shukri H, Mahmood R, Khalid LB. Effect of Salvia officinalis L. (Sage) Aqueous extract on Liver and Testicular Function of Diabetic Albino Male Rats. Journal of Babylon University/Pure and Applied Sciences 2016; 2(24): 390-399.

49. Yinroglu L Yeap F Pollyphenolics of salvia- a review. Phytochemistry 2002; 59 (2): 117-140.

50. Hasan K, Hilal BA, Erika LB, Annamaria Z, Erden Y, Judit H Chemical constituents of Salvia dichroantha. Biochemical Systematic and Ecol 2012; 42: 18-20.

51. Hamdy Roby MH, Sarhan K, Abdel-Hamed Selim, Khalel KI Evaluation of antioxidant activity, total phenols and phenolic compounds in thyme (Thymus vulgaris L.), sage (Salvia officinalis L.), and marjoram (Origanum majorana L.) extracts," Industrial Crops and Products 2013; vol. 43, pp. 827-831.

52. Stephan GW, Tinzoh LN, Zimmermann BF, Stühlinger $W$, Lachenmeier DW Antioxidant capacity and polyphenolic composition as quality indicators for aqueous infusions of Salvia officinalis L. (sage tea). J. Ethnopharmacology 2011; (2); p: 1-6.

53. Grzegorczyk I, Matkowski A, Wysokinska H Antioxidant activity of extracts from in vitro cultures of Salvia officinalis L. Food Chemistry 2007; 104 536-541.
54. Affanas, s EVIB, Dorozkvo Al, Brodskii AV, Kostyuk VA, Potapovitch Al. Chelating and free radical scavenging mechanisms of inhibitory action of rutin and quercetin in lipid peroxidation. Biochem. Pharmcol 1989; 38: 1763-1769.

55. Hanasaki Y, Ogawa S, Fukui, S The correlation between active oxygens scavenging and antioxidative of flavonoids free radical. Biol. Med 1994 ; 16: 845-850.

56. Horvathova K, Novotny L, Vachalkova A The free radical scavenging activity of four flavonoids determined by the comet assay. Neoplasma 2003; 50(4): 291-295

57. Park YC, Rimbach G, Saliou C, Valacchi G, Packer L Activity of monomeric, diameric and trimeric flavonoids on NO production, TNF-a secretion and NF-kappaB-depentent gene expression in RAW 264.7 macrophages. FEBS. Lett 2000; 464(2-3): 93-97.

58. Khaki A, Fathiazad F, Nouri M, Khaki A, Maleki NA, Khamnei HJ, Ahmadi $P$ Beneficial effects of quercetin on sperm parameters in streptozotocin-induced diabetic male rats. Phytotherapy Research 2010; 24(9), 1285-1291.

59. Agrwal A, Prabakaran SA, Said TM. Prevention of oxidative stress injury to sperm. J. Androl 2005;26(6): 654-660.

60. Sheweita SA, Tilmisany AM, Al-Sawaf H Mechanisms of male infertility: role of antioxidants. J. Curr. Drug. Metab 2005; 6 (5): 495-501. 

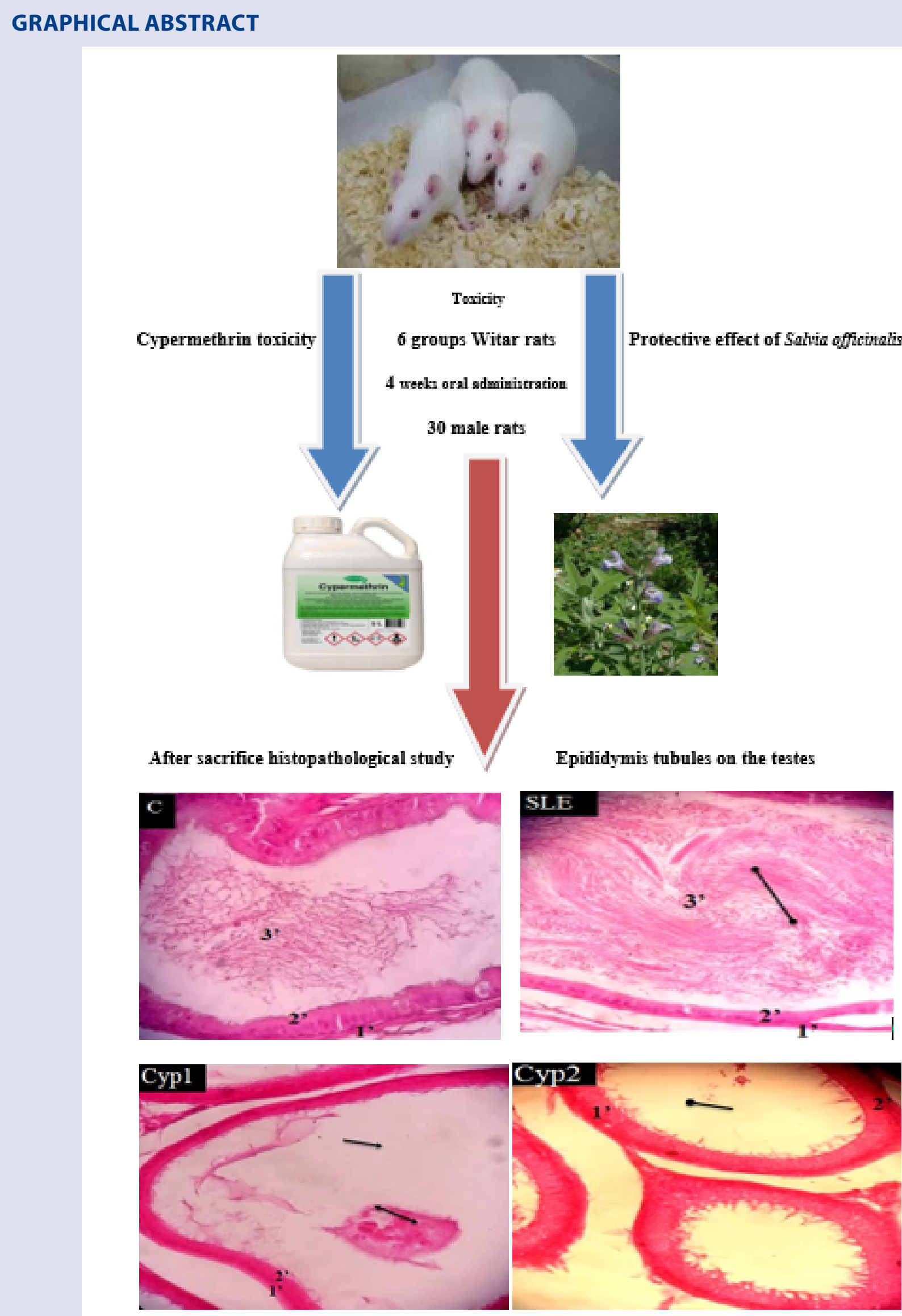


\section{ABOUT AUTHORS}

- Amel CHOUABIA: Dr in Department of Biology, Faculty of Science Badji Mokhtar Annaba University Algeria, Animal Ecophysiology Laboratory. She is teacher, research since 2009.Skills: Ecophysiology, Animal biology and reproduction.

- Samir DJEMLI: Lecturer in Department of Biology, Faculty of Science Badji Mokhtar Annaba University Algeria, Applied Neuroendocrinology Laboratory. I am teacher research since 2009. Skills: Neurobiology, Toxicology, Biochemistry, Animal Biology, Neurophysiology.

- Cherif ABDENNOUR: Pr in Department of Biology, Faculty of Science Badji Mokhtar Annaba University Algeria, Animal Ecophysiology Laboratory. He is teacher research since 1995. Skills: Ecophysiology, Animal biology and reproduction.

- Leila MALLEM: Phd Student in Department of Biology, Faculty of Science Badji Mokhtar Annaba University Algeria, Animal Ecophysiology Laboratory. She is Phd Student since 2017.Skills: Ecophysiology, Animal biology and reproduction.

- Labiba KAHALERRAS: Phd Student in Department of Biology, Faculty of Science Badji Mokhtar Annaba University Algeria, Animal Ecophysiology Laboratory. She is Phd Student since 2016.Skills: Ecophysiology, Animal biology and reproduction.

- Fatma Zohra ARKOUB: Phd Student in Department of Biology, Faculty of Science Badji Mokhtar Annaba University Algeria, Animal Ecophysiology Laboratory. She is Phd Student since 2016.Skills: Ecophysiology, Animal biology and reproduction.

- Narimene BOUABDALLAH: Phd Student in Department of Biology, Faculty of Science Badji Mokhtar Annaba University Algeria, Animal Ecophysiology Laboratory. She is Phd Student since 2018.Skills: Ecophysiology, Animal biology and reproduction.

- Abdelkrim TAHRAOUI: Pr in Department of Biology, Faculty of Science Badji Mokhtar Annaba University Algeria, Applied Neuroendocrinology Laboratory. He is teacher research since 1981.Skills: Neurobiology, Toxicology, Biochemistry, Animal Biology, Neurophysiology.

Cite this article: CHOUABIA A, DJEMLI S, ABDENNOUR C, MALLEM L, KAHALERRAS L, ARKOUB FZ, et al. Protective effect of Salvia officinalis against cypermethrin-induced reprotoxicity in male Wistar rats. Pharmacogn J. 2021;13(6): $1413-1421$. 